This item was submitted to Loughborough's Research Repository by the author.

Items in Figshare are protected by copyright, with all rights reserved, unless otherwise indicated.

\title{
Entrepreneurial decision-making in internationalization: propositions from mid-size firms
}

\section{PLEASE CITE THE PUBLISHED VERSION}

https://doi.org/10.1016/j.ibusrev.2007.10.001

\section{PUBLISHER}

(C) Elsevier

\section{VERSION}

AM (Accepted Manuscript)

\section{PUBLISHER STATEMENT}

This work is made available according to the conditions of the Creative Commons Attribution-NonCommercialNoDerivatives 4.0 International (CC BY-NC-ND 4.0) licence. Full details of this licence are available at: https://creativecommons.org/licenses/by-nc-nd/4.0/

\section{LICENCE}

CC BY-NC-ND 4.0

\section{REPOSITORY RECORD}

Perks, Keith J., and Mathew Hughes. 2019. "Entrepreneurial Decision-making in Internationalization: Propositions from Mid-size Firms". figshare. https://hdl.handle.net/2134/26380. 


\title{
Entrepreneurial Decision-Making in Internationalization: Propositions from Mid-size Firms.
}

\begin{abstract}
Research into international entrepreneurship tends to focus on new ventures rather than larger established firms. Few studies have considered why an entrepreneurial manager in an established firm is motivated to undertake international market entry. Propositions relating to factors motivating the international market entry decision of entrepreneurial managers in midsized firms are created and evaluated through in-depth interviews with entrepreneurial managers. We find contrary to extant theory that cultural context, industry environment and resource constraints do not motivate or hinder an entrepreneurial manager's decision to internationalize. Rather, the entrepreneurial manager's connection with the customer, tacit knowledge and vision and product-service complexity are the strongest influences on the decision to internationalize, which is moderated by the strength of the business case and resource-based risk tolerance. This implies a much greater strategic approach by entrepreneurial managers than typically portrayed in current literature. Our research provides researchers with grounded propositions for further empirical testing.
\end{abstract}

Key-words: Entrepreneurial managers; international entrepreneurship; market entry; opportunity; risk tolerance. 


\section{Introduction}

International entrepreneurship emerged as a field of study in the 1990s in entrepreneurship and international business studies. International entrepreneurship is multidisciplinary drawing on a diverse range of theories from international business, entrepreneurship, economics, psychology, anthropology, finance, marketing and sociology (Oviatt \& McDougall, 2005). However, there remains limited theoretical development (Dimitratos \& Jones, 2005; McDougall \& Oviatt, 2000), rendering the field subject to criticism for the rigor of its conceptual base prior to in-depth empirical work.

The challenge of theoretical development was taken up by Jones and Coviello (2005) who presented a theoretical framework encapsulating both the behavioural and temporal nature of entrepreneurship in connection with some dynamics of international business strategy. Significantly more research that is grounded in a synthesis of the entrepreneurship and international business literature has been called for (Zahra \& George, 2002). Moreover, there have been calls for new directions and theories in the international business literature with one avenue being a return to a focus on international business strategy at the firm level (Peng, 2004). In our study, we seek to address these three key issues by synthesizing literature on entrepreneurship and international business, focusing on international business strategy, and studying these relationships at the manager level in mid-sized enterprises. Our research aims to develop a set of propositions from the literature which can be used to examine and observe the international market entry decision of entrepreneurial managers in mid-sized firms. Market entry decisions represent the central component of an entrepreneurial business strategy (Lumpkin \& Dess, 1996).

Research into international entrepreneurship has tended to focus on small firms at the cost of understanding the phenomenon in larger, established firms, however Dimitratos and Jones (2005) and Zahra and George (2000) contend that international entrepreneurship theory 
needs to be extended to larger, established firms and other traditional sectors. We agree and contest that the locus of entrepreneurship is not defined by firm size or age but rather by opportunity. Such a perspective is congruent with studies that place emphasis on the competitive value of entrepreneurship (Lumpkin \& Dess, 1996), the behaviour of firms and their managers (McDougall \& Oviatt, 2000), the benefits of opportunity identification and exploitation (Stevenson \& Jarillo, 1990), and the potential for firm growth by leveraging resources and capabilities in foreign markets (Zahra \& Garvis, 2000).

While studies have considered what established firms might do to accrue improvement in firm performance from international entrepreneurship (Zahra \& Garvis, 2000), few studies have considered why an established firm undertakes international entrepreneurship. As a result, we know little about what affects the inclination of an entrepreneurial manager to internationalize or what motivates or constrains the internationalization decision (Westhead, Wright, \& Ucbasaran, 2001). In response to this gap, we seek to address the following research question: Why do entrepreneurial managers in mid-sized firms take the decision to internationalize and enter foreign markets? The objective is to understand the drivers of the fundamental entrepreneurial problem of international market entry (Lumpkin \& Dess, 1996) in contrast to studies that have predominantly focused on the internationalization strategies of firms (Wind, Douglas, \& Perlmutter, 1973). In responding to this question, we seek to develop a holistic view of factors that motivate the act of international market entry.

\section{Theoretical Development}

\subsection{Definition of International Entrepreneurship}

Entrepreneurship has been defined as the act of market entry whereby the entrepreneurial manager in a firm must decide what markets to enter, when and how (Lumpkin \& Dess, 1996). This definition is broadly applicable to any firm and is not specific 
in any way to small firms. As such, the locus of entrepreneurial activity is defined by the act and not the firm. Entrepreneurship has been further defined as the identification and pursuit of opportunity regardless of the firm's current resources (Stevenson \& Jarillo, 1990). The decision faced by the entrepreneurial manager is then one of strategising how and when to enter a market in pursuit of an opportunity, which reflects an act rather than an event. The question of international entrepreneurship thus becomes what triggers that act.

To reconcile with definitions of international entrepreneurship, early definitions of the concept focused on the international activities of new venture firms to the exclusion of established firms but such a limited definition is increasingly viewed as inferior (McDougall \& Oviatt, 2000). Wright and Ricks (1994) defined international entrepreneurship as firm-level business activity that crosses national borders and such activity focuses on the relationship between businesses and the international environments they operate in. Whilst such a definition has merit as it highlights the role of market entry, there remain underlying limitations since the act of entrepreneurship is unclear. McDougall and Oviatt (2000) refined this view to define international entrepreneurship as a combination of innovative, proactive and risk-seeking behaviour that crosses national borders and is intended to create value in firms. Firm size and age are not defining characteristics and such behaviour may occur at the individual, group or firm level. This definition is further advantageous because the decision to internationalize and thereby undertake risk by crossing national borders to enter international markets is implied as the defining act.

By synthesising the perspectives offered in these studies, we view international entrepreneurship as innovative, proactive or risk-taking behaviour of an actor (firm or individual) to undertake cross national border activity through the act of international market entry. Firm size and age do not define the activity, nor does the internationalization event itself. The defining characteristic is the act of international market entry and the locus of our 
study therefore is how an entrepreneurial manager makes this decision to act (Lumpkin \& Dess, 1996; McDougall \& Oviatt, 2000). Insufficient treatment exists in the international entrepreneurship literature on established firms despite the importance attached to their capacity to act entrepreneurially, generate new business and expand internationally (Zahra \& Garvis, 2000). In the U.K., mid to large firms contribute 63 percent of U.K. turnover (DTI, 2004).

It is also necessary to define the entrepreneurial manager. The entrepreneurial manager represents the focus of our study because it is not firms who make decisions but managers. When we examine for external business environment and internal firm environment conditions affecting the decision to internationalize, we assess them in the context of how these factors influence an entrepreneurial manager to choose to exploit an opportunity to internationalize. This is in line with our research question. It is the entrepreneurial manager who must be willing to allocate scarce resource to meet opportunities for international market entry that carry highly uncertain outcomes with no guarantee of return (Lumpkin \& Dess, 1996; McDougall \& Oviatt, 2000). Larger established firms are often slower to respond to opportunity than smaller firms and therefore understanding the factors impinging on an entrepreneurial manager's decision to internationalize are important to appreciating why this often remains the case (Dean, Brown, \& Bamford, 1998).

\subsection{Theories on the Internationalization of Firms: External Factors}

The majority of internationalization theory in both international entrepreneurship and international business research has tended to examine external environment factors as determinants of the decision to accept an international market entry opportunity. For example, in international product life cycle theory (Vernon, 1966) internationalization is explained in a chain of four stages where a firm internationalizes according to a point in time where it needs to grow its product sales. This theory, however, does not consider the nature of 
internationalization decision-making and ignores broader firm and individual managerial factors that might influence the process. Market imperfection theory on the other hand explains how a firm with limited knowledge of foreign local conditions can successfully overcome competitive disadvantages through foreign direct investment (FDI) (Hymer, 1976). Whilst this approach highlights the importance of environmental conditions, it too does not explore the nature and context of international decisions and is overly focused on market conditions as opposed to what a firm or individual might do to manage conditions prior to internationalization and so motivate the decision to internationalize.

Strategic behaviour theory (Knickerbocker, 1973) is somewhat an extension of the market imperfection theory and offers the dynamics of international competition as an explanation for patterns of FDI. This theory argues that firms tend to resort to matching the strategic behaviour and actions of their rivals to minimize risk and uncertainty. A further consideration in this regard is culture theory (Hofstede, 1980) which implies that internationalization requires a firm to understand the different cultures at play in these markets and consider what effect these might have on the product or service of the firm and its typical market strategies. The greater the cultural difference, the greater the uncertainty to an entrepreneurial manager but also the greater the potential competitive disadvantage to the firm relative to firms already serving those international markets. It remains unclear the extent to which national, regional or local cultures have an impact or not on international entrepreneurship. Studies and theories from cognitive psychology and sociology (Zahra, Korri, \& Yu, 2005) suggest that cross-cultural factors might influence an entrepreneur's decision-making and thus warrant consideration.

The stage theory of internationalization (Johanson \& Vahlne, 1977) linked to early and late modes of international entry, from exporting to full commitment in the form of FDI generally presents internationalization as a unidirectional linear process, and is similar to the 
international product life cycle theory. This internationalization process theory is similar to learning models (Andersen, 1993) as it contains the dynamics of learning and process of adapting to foreign market knowledge and increased market commitment consequently. As this process evolves the firm builds its experiential knowledge and firm specific resources and capabilities, similar to the resource advantage theory (Hunt, 2002).

A further manner in which international market entry might be motivated is through relationships with customers. Cardone-Riportella, Álvarez-Gil, Lado-Cousté, and Sasi (2003) state one of the dominant features of internationalization to be customer-following or marketseeking behaviour brought about by close ties between the firm and its key customers. When these ties are close, they can motivate internationalization by reducing perceived risk. For example, as Calantone, Cavusgil, Schmidt, and Shin (2004) observe, pre-existing customer linkages and relationships influence whether or not substantial adaptation to products will likely be needed prior to the pursuit of internationalization. The degree of adaptation will likely depend on the complexity of the product and thus the ability of international customers to rapidly understand how to make best use of the product (Thompson, Hamilton, \& Rust, 2005). This factor is complicated by the sophistication of customers in international markets.

Taking the above into consideration, we can draw out some important points to form propositions on factors motivating an entrepreneurial manager's decision to internationalize. The role of the external environment is important since no firm can operate independently from its market context and so our conceptual framework considers customer linkages and product complexity as key factors. In addition, industry theories suggest that irrespective of customer linkages, one cannot discount the industry environment as entry conditions must be favourable to facilitate internationalization. Also, the culture of the domestic market versus international market warrant inclusion since Kim and Kang (2001) imply that customers across markets are not homogeneous and so market conditions will be a consideration for 
entrepreneurial managers. International business and cross cultural research has for some time examined the impact of cultural distance on new market entry with most studies finding managers tending to enter new markets that have similar languages, business systems, level of economic development and cultures to their own (Johanson \& Vahlne 1977).

The fundamental problem with theories on external forces however is if external environment conditions are favourable, why do all firms in the industry not internationalize? Irrespective of the favourability of the external business environment, firms still behave heterogeneously and so a second range of factors must be at play. Research suggests this may be due to internal constraints such as lack of financial resources and the international experience of an entrepreneurial manager (Peng, 2001; Reuber \& Fischer, 1997).

\subsection{Theories on the Internationalization of Firms: Internal factors}

Westhead et al. (2001) argue that some firms neither have the inclination nor the ability to internationalize. Irrespective of the appeal of an international market entry opportunity therefore, a set of internal factors constrains a decision to pursue the opportunity. Studies tend to converge on resources and knowledge as decision drivers since weaknesses in these resemble varying types of liability to the established mid-sized firm (Henderson, 1999). Accordingly, the resource-based view and knowledge-based view warrant consideration.

Resource advantage theory assumes that some firms have size and scope advantages over others (Wernerfelt, 1984). Applied to the global market, resource advantage theory builds on international trade theory of comparative advantage to explain decisions to internationalize whereby firms can exploit comparative capabilities, skills and resources for sustainable competitive advantage in international markets (Andersen, 1997).

Zahra and Garvis (2000) argue that internationalization presents an opportunity for established firms to leverage their resources and skills but assumes that sufficient slack exists and that the firm has a contemporary product offering considered desirable by the market. 
However, following views on liability of obsolescence, this may not be the case for many established firms (Henderson, 1999). In pursuing international opportunities, the entrepreneurial manager must assess whether devoting scarce resources under uncertain market conditions is worthwhile given the opportunity cost of diverting resources from existing operations. The firm's accumulated tangible and intangible resource stocks and the extent to which these are valuable, inimitable, non-substitutable and rare indicate whether the firm will be at an advantage or disadvantage when making a decision to enter international markets (Leiblein \& Reuer, 2004). However, this is complicated by liability of foreignness which results from unfamiliarity with international market environments owing to lack of knowledge and experience (Zaheer, 1995). As a result, entrepreneurial managers must look for compensating, resource-based advantages (Leiblein \& Reuer, 2004). In the absence of such conditions, entrepreneurial managers are highly unlikely to internationalize. This is not caused by risk aversion but rather risk management to mitigate unnecessary harm.

Liability of foreignness theory indicates that where entrepreneurial managers lack knowledge and experience of operating internationally, they experience distinct problems in deducing fit between the international market and their product-services. However, experience brings with it its own problems as the firm and its managers may have learned incorrect knowledge or developed inaccurate assumptions such that past lessons learned may hinder future opportunity exploitation as they may not necessarily be applicable in different contexts (Brannen, 2004).

When the firm's management team, in particular the entrepreneurial manager, possess past experience of international markets or the process of internationalization, those experiences will shape a specific knowledge base and expectancy of the nature and process of internationalization (Arthanassiou \& Nigh, 2000). The international development of firms is 
often characterized as path dependent based on the development of the manager's experiences and knowledge as well as the resources available to them (Collis, 1991).

The entrepreneurial manager’s specific knowledge base can also impact opportunity identification and exploitation. Opportunity discovery is a function of knowledge but equally so is its exploitation. The exploitation of an opportunity cannot be explained by the mere allocation of resources. It benefits from repeat opportunity exploitation experience which builds tacit knowledge of the process. The presence of prior international experience (Reuber \& Fischer, 1997) and further learning through opportunity exploitation in practice, regardless of context, will likely increase the entrepreneurial manager's favourability toward internationalization. This increased knowledge helps the entrepreneurial manager to manage the risk posed by international market entry and mitigate the liability of foreignness.

From this discussion, we can draw out a number of internal firm conditions that warrant inclusion in a holistic set of factors motivating an entrepreneurial manager's decision to internationalize. These include resource availability, historical past and previous decisions, and the entrepreneurial manager’s tacit knowledge of opportunity exploitation.

\section{Proposition of Factors Influencing the Market Entry Decision of Entrepreneurial}

\section{Managers}

Studies in the field of population ecology (Hannan \& Freeman, 1977) and entrepreneurship (Zahra, 1993) recognize that the environmental context shapes entrepreneurial strategies in particular internationalization (Garner, 1982; Rao, 1990). Customer preferences and the demands they make on suppliers affect internationalization decisions (Bell, 1995). For example, a domestic or international customer may require a supplier to sell directly to its subsidiaries in international markets. On the other hand the 
customer's industry environment may pull the supplier towards the home market if the customer's industry is domestic.

Proposition 1. The entrepreneurial manager's decision to internationalize is sensitive to and influenced by the industry environment in which the firm operates.

Culture has been defined as the shared values, beliefs and expected behaviours at a societal or organizational level (Hofstede, 1980) that shape political institutions as well as social and technical systems, simultaneously reflecting and reinforcing values and beliefs. The extent to which a society considers entrepreneurial behaviour to be desirable is dependent on the degree that its members perceive risk taking and independent thinking to be positive or negative attributes (Hayton, George, \& Zahra, 2002). International entrepreneurship by its very nature crosses over into other nations, regions and cultures and raises the question concerning entrepreneurial behaviour of whether it has a universally common meaning or 'culture' (Mitchell et al., 2002; Mitchell, Smith, Seawright \& Morse, 2000) or is subject to different meanings depending on complex cultural influences (Busenitz, Gomez, \& Spencer, 2000). Others have identified that there are problems of associating a culture with a nation as they are not totally synonymous as cultures cut across nations (Tan, 2002). For our research we assume that culture is synonymous with the nation and country. Entrepreneurial managers may be more or less likely to make the international market entry decision depending on the influence of the strength or weakness of cultural values such as risk avoidance or individualism or collectivism inherent in a society. Conversely, entrepreneurial values such as risk taking and individualist behaviour, may be universal attributes and affects entrepreneurial managers equally. Further, entrepreneurial managers may decide to enter international markets stimulated and influenced by the cultural closeness of a particular foreign market.

Proposition 2. The entrepreneurial manager's decision to internationalize is influenced by their home country cultural environment. 
The decision to internationalize may vary depending upon the nature of the product and service (Cloninger, 2004). Domestic customers with foreign operations or foreign customers may request a firm to supply them with complex products and services (user education, customization) and users may want a direct relationship with the original source of the technology (Rangan, Menezes, \& Maier, 1992). Further, in the innovation literature (Urban \& von Hippel, 1988) in high technology and mature product categories the lead user customer plays a critical role in the development of innovative products in collaboration with the supplier. Trabold (2002) also found that product complexity could influence the international market entry decision because of the need for user education and support.

Proposition 3. The entrepreneurial manager's decision to internationalize is influenced by products and services that require a high involvement from users.

In business marketing, buying attitudes are influenced by a group of professional decision-makers who tend to develop relationships with suppliers and customers over time (Ford et al., 1998). A customer orientation construct broadly represents businesses focusing activities on the interaction and relationships with customers for improved performance and competitive advantage (Homburg, 2000). New perspectives on marketing have emerged with a shift from an emphasis on the exchange of tangible goods and transactions to an emphasis on intangible resources and services. These perspectives have spawned what some authors argue is a new paradigm of marketing (Vargo \& Lusch, 2004) as a social and economic process (market orientation, services marketing, relationship and network marketing). Buyers may be important for strategic reasons, or because the relationship contributes a significant level of revenues or profits (Campbell \& Wilson, 1996). Consequently, the level of international involvement by the seller (the entrepreneurial manager) should rise as the significance of the relationship increases. In the internationalization process of the firm, domestic and international customer, supplier, competitor and other networks also act as an 
influence (Coviello \& Munro, 1995). Consequently, the entrepreneurial manager's decision to internationalize will likely be influenced by the degree to which they internalize the customer and other network actors in marketing processes and the firm's inclination to hold close linkages with them. Close linkages with other firms in a network exposes an entrepreneurial manager to idiosyncratic sources of knowledge. By developing sufficient social capital and embedding the firm in close ties, entrepreneurial managers can draw on the experience of others and learn knowledge that might stimulate a decision to internationalize. Further, through network relations, firms can draw on external resources to aid in the internationalization process. In doing so, the risk of internationalizing is reduced as managers can collaborate with key customers and partners to ensure international activities have a better chance of success.

Proposition 4. The entrepreneurial manager's decision to internationalize is influenced by the strength of its customer and network relationships.

The resource-based view (Wernerfelt, 1984) has, as its central tenet, the idea that valuable, rare and inimitable resources and capabilities form the basis of competitive advantage. Resources can limit decision-makers options and firm growth and so serve as a barrier to the internationalization of mid-sized firms (Kedia \& Chokar, 1986). Limitations in the availability of resources prevent entrepreneurial managers from structuring, bundling and leveraging novel combinations of resources to create new sources of value for customers (Sirmon, Hitt, \& Ireland, 2007). Without sufficient resources, entrepreneurial managers would be faced with tradeoffs in undermining existing activities to pursue uncertain international opportunities.

Proposition 5. The entrepreneurial manager's decision to internationalize is influenced by the availability of adequate internal resources. 
The history of small-to-medium sized entrepreneurial organizations is strongly related to the attitudes and preferences of the top managers. Decision-makers may pursue similar patterns and practices to those developed in the domestic market in international markets following a ‘path dependency’ (Nelson \& Winter, 1982). International decisions are often a simple function of the experience and prior pattern of behaviour of the entrepreneur and prior international experience has been suggested as an important determinant of the decision to internationalize (Dichtl, Koeglmayr, \& Mueller, 1990).

Proposition 6. The entrepreneurial manager's decision to internationalize is influenced by their prior history of decision-making.

Research adopting the resource-based view has regarded the entrepreneur's mindset and thinking as a resource (Lumpkin \& Dess, 1996) influencing decision-making and is an important unit of analysis impacting on strategic processes and behaviour. Gimeno, Folta, Cooper and Woo (1997) found that the economic survival of the firm was a function of the internal attributes of the organization and in particular the human capital attributes of managers. In the context of internationalization theory, an organization's internationalization may be contingent upon both the entrepreneurial manager as a resource and the decisionmaking methods deployed by the entrepreneurial manager. Therefore, how mid-sized firms internationalize hinges on their exceptional tacit knowledge about international opportunities (Peng, Charles, \& Wang, 2000) ability to transfer product knowledge and capabilities developed in the domestic situation transferred to international markets (Madhok, 1997) and an advanced capability to leverage such knowledge (Mitchell et al., 2000). Consequently, the decision to internationalize can be determined by the initial founding conditions of the organization, which includes the entrepreneurial manager's or team's experience (Reuber \& Fischer, 1997). 
Proposition 7. The entrepreneurial manager's decision to internationalize is influenced by their tacit knowledge about international opportunities and how to leverage capabilities.

\section{Research Methodology}

\subsection{Epistemological position and investigation method}

The desire to explore our propositions guided our strategy to adopt case studies as a method (Yin, 1994) to give valuable insight into whether these theoretically-derived propositions in fact are relevant to mid-sized firms. Such a qualitative approach allows us to observe, refine and develop further the propositions outlined herein. Our method of using indepth interviews and open questions allowing for probing and discussion of issues was supplemented by internal and external sources such as company reports and internal memos. Our informants were top-level owners/board members/managers responsible for making internationalization decisions. The use of extended questioning and discussion with entrepreneurial managers with a free flow of responses generates rich data and unravels the complexity and holistic nature of management issues and decision-making (Gummesson, 2006). Through coding and analysis of interviews and documents we could examine patterns of responses which were common or unusual. From this we can get a sense of whether an issue or influence is important or not in the international decision-making of entrepreneurial managers. The particular strength of this method is the collection of rich data, in vivo, facilitating the evaluation of interrelated definitions and propositions and the exploration of the relations between them. The approach here is 'theory-first', whereby theory is developed via a 'deductive strategy' with the researcher identifying orienting constructs and propositions to test or observe in the field (Miles \& Huberman, 1994). A case study reveals theoretical relations in situ and can be used to uncover processes that link inputs and outputs within a 
system (Lacey, 1976). This implies that the researcher may literally see these processes occur (Glaser \& Strauss, 1967). The methodology for the research does not seek to apply a sampling logic because it would be 'misplaced' (Yin, 1994). The group of firms do not represent the total population, as we were not looking for the frequency of a particular phenomenon. The research is based on sixteen case studies developed from interviews. The 'ideal' number of cases is, in the main, judgmental (Yin, 1994) and it would also be inappropriate in the light of our methodology to imply a calculated sample size.

The interview data was compared with data from company documents to improve validity and accuracy of our analysis and discussion in an effort towards triangulation. All responding firms provided us with information ranging from internal company documents, catalogues, books, annual reports and press cuttings. This method helps to overcome the problem of 'mistaken' memories on the part of interviewees as it facilitates confirmation of a statement(s).

\subsection{Criteria for selecting the case study sites}

The first criterion for selecting our cases is country location of the firm. We drew on a sampling frame of 500 medium-sized firms and purposefully selected 30 organizations in four European countries, namely, Germany, Britain, France and Italy. Of these 30 organizations 16 of them agreed to participate in our study. The organizations matched the requirements for our purposeful sampling method. These countries represent the four major European economies and also offer potential for examining the influence of cultural similarities as there are common cultural values such as individualism/collectivism index for Germany, Italy the UK and France. However there is potential for some differences in for example the power distance index (PDI) where France has a larger PDI than Germany, Italy and the UK. Further, on the uncertainty avoidance and masculinity index Italy and Germany are in the same cluster and Britain and France in different clusters allowing for potential commonalities and differences 
influencing an entrepreneurial manager's decision to internationalize their firm (Hofstede \& Hofstede, 2005). The second criterion is firm size and ownership status. Past research on internationalization has focused typically on small high technology firms in rapidly globalizing international markets and less on larger established firms. From 2000 onwards the fastest growing companies in Europe were in the medium-size group of companies (100 to 999 employees), sustaining an annual turnover growth rate of $16 \%$ higher than the European average of 14\% (Europe's 500, 2005).

We adopted the number of employees accordingly as a measure of firm size as this is the most commonly used in research and policy (Coviello \& Jones, 2004). All of the firms were independently owned (no more than $50 \%$ of outside shareholder involvement). Further, each firm had to have $10 \%$ or more of their sales derived from export. Whilst this may appear a low proportion the figure of $5 \%$ is commonly used as a benchmark to determine an export company (Bürgel, 2000). Table 1 summarizes the profiles of each case study in the research.

\subsection{Data coding and analysis}

The coding system applied was based on the structure of our interview protocol (Appendix 1) used in the process of interviewing and was analyzed in two stages allowing for several iterations and interpretations from micro-analysis to the linking of concepts and propositions (Strauss \& Corbin, 1998). The first level of analysis coded the documents into 28 free nodes within 'Nvivo' software. The coding structure and content was developed around the questionnaire and adjusted as new codes emerged. This enabled us to identify cross-case patterns, replications and differences. The second level of coding and analysis in this stage broke the data down to develop the influences on internationalization and the propositions. The data was coded into 'tree-nodes' that linked the data to the propositions.

Insert Table 1 about here 


\section{Analysis and Discussion of Research Propositions Based on Research Findings}

This section of the paper analyses and interprets the data to explore and explain factors influencing the entrepreneurial manager's decision to internationalize and so undertake the act of international entrepreneurship. We suggest some tentative findings regarding the strength of each factor's influence on the international decision-making of the entrepreneurial managers in our study.

Proposition 1. The entrepreneurial manager's decision to internationalize is sensitive to and influenced by the industry environment in which the firm operates.

Most of the industries served by the firms studied are international in nature and so push firms to engage in international activities. The software firms are linked to international banking, large projects, global software houses, telecommunications, retailing, information technology, and pharmaceuticals. The electronic firms serve international clients in the automobile, medical, retail, telecommunications, information technology, and computer games industries. The engineering firms supply the global automobile industry, mobile communications, international projects, domestic appliances, medical, and military markets. For many of the firms the industry environment can so be classed as global or international in nature. The combination of both an internationally focused supplier industry and customer industry may be thought to exert a strong influence on the internationalization process of the case study firms. Only one entrepreneurial manager, however, explicitly acknowledged the influence of the industry environment:

"The internet is the driving force of our industry yes definitely. The PC periphery business and client access business is a global industry and either you play in a global dimension or you don't play" (respondent case 6).

One possible explanation is that the entrepreneurial manager follows multinational customers into international markets. Consequently they are perhaps more focused on the 
immediate micro-customer environment rather than the distant macro-industry environment. A more likely explanation might be that the nature of the industry is but one consideration. Although one school of thought suggests that managers behave in accordance to their industry, other schools such as the resource-based view argue that the manager will take into account their stock of unique resource endowments, given external opportunities and constraints, and rather are more concerned with their firm's ability to meet the demands of internationalization rather than be governed by industry structure (Ekeledo \& Sivakumar, 2004). This is interesting since these firms do not possess liabilities of newness (as they are established and of medium size) but on the other hand are more likely to want to consider carefully how best to utilize their value-creating resources to achieve the most value. This orients the manager to think internally rather than externally it would appear.

The degree of sensitivity of a manager's internationalization decision-making, it could be suggested, relies perhaps on balancing the resource set with the nature of the industry. This observation explains the growing interest in the resource-based view in international research (Peng, 2001) and explains why favourability of an industry structure in and of itself will not motivate an entrepreneurial manager to internationalize. Curiously, this suggests that entrepreneurial managers are more careful than the risk-taker view typically presented in treatments of IE so far (e.g., McDougall \& Oviatt, 2000) On balance, despite the intuitive appeal of drawing on industry environment as an explanatory variable of international decision-making, it should be viewed as one cog in a holistic decision-making process. Industry appears to provide opportunity to internationalize but in mid-sized firms does not motivate internationalization.

Proposition 2. The entrepreneurial manager's decision to internationalize is influenced by their home country cultural environment. 
The results for influence of national culture on internationalization are contrary to some of the literature on cross-cultural and entrepreneurial management (Busenitz et al., 2000). Few respondents considered national culture as a significant issue. This finding supports Mitchell et al. (2002; 2000) who found a common cultural perception of entrepreneurship, which suggests that entrepreneurial managers are more concerned with how they could enter a market with advantage than any inherent cultural difference. It appears therefore that entrepreneurial managers are not particularly attached to their home country and consequently their standard 'home' cultural values. Equally, they do not appear concerned with the cultural values of non-domestic countries. Accordingly, cross-cultural differences appear to have little effect on their decision-making. The decision to internationalize then appears to be based purely on a business case than a cultural one suggesting entrepreneurial managers behave much more strategically than is typically acknowledged (Ireland, Hitt, \& Sirmon, 2003).

In our analysis of responses from the entrepreneurial managers and literature on 'psychic' distance (Sousa \& Bradley, 2006), we find that the entrepreneurial manager's ability or inability to deal with different languages and cultures did not prevent the entrepreneurial managers in our study from internationalizing and so they are not seen as significant barriers to internationalization.

However, entrepreneurial managers will have personal perceptions of the psychological distance of foreign markets from their domestic market, known in the literature as 'psychic' distance. The concept of 'psychic' distance is defined as factors preventing or disturbing the flow of information between potential or actual suppliers and customers (Nordström \& Vahlne, 1994). Psychic distance is regarded as a broader concept than culture as it embraces factors such as the similarities or differences in the economic development, level of education, 'business language' between the home and host country, previous trading 
links between the home and host countries as well as culture and language (Johanson \& Vahlne, 1977). In a re-think and debate of the concept Sousa and Bradley (2006) argue that while the 'psychic' distance concept is related to culture it is fundamentally different as the former is concerned with the individual's personal psyche and the latter a result of broader external cultural values determined by for example family, education and religion. Thus, following Sousa and Bradley we suggest that psychic distance cannot be measured by for example economic indicators and the unit of analysis must be the individual. In re-examining proposition 2 in the light of the subtle distinction between externalized cultural values and internalization of 'psychic' perceptions we found that few entrepreneurial managers discussed the external cultural values such as individualism or uncertainty avoidance. Rather they articulated their personal perceptions of 'psychic' distances of new markets when deciding on new market entry.

"It really becomes difficult with these external organizations where there is also the culture and the language system that is different (respondent case 2).”

"The mentality of Italian entrepreneurs is we are good on technological processes good technical developers but we are no good for example at languages and exporting (respondent case 10).”

These are personal reflections on their preferences for entering new markets which are psychologically close to them. Despite most entrepreneurs pursuing the business case, it also appears that some do fear the language differences, implying that entrepreneurial managers are not homogenous in their degree of confidence. Skills might be the answer to this point but it is more likely a case of risk-tolerance, which goes against the standard view in IE theory that all international entrepreneurs deliberately seek risk (McDougall \& Oviatt, 2000).

The above quotes suggest that the educational context within the home country may be influential on an entrepreneurial manager's openness to exploiting international market 
opportunities. If the education system emphasizes the development of foreign language skills then this may ultimately serve to encourage the internationalization of firms within that country. As such this suggests there can be varieties in the national environmental conditions for stimulating internationalization (e.g., Wong, Ho, \& Autio, 2005). This finding however appears somewhat at odds with Dwyer, Mesak, and Hsu (2005) who found that broad national culture types influenced the cross-national diffusion of innovations. Since our research relates to internationalization as opposed to only the cross-national diffusion rates, it would seem that research is needed to reconcile the influence of culture on post internationalization performance in addition to pre-internationalization expectancies. Whilst culture may not have hindered internationalization in the firms we studied in terms of forming a decision to internationalize, it would be valuable to discover if this triggered naivety in entry and postentry strategy.

On the basis of our qualitative analysis and the literature we have refined our original proposition 2 from externally derived cultural influences and consider the entrepreneurial managers' internalised perceived psychic distance between the home and foreign market to be an influence on their international market entry decision. Thus:

New proposition. Perception of a 'psychic distance between their home and foreign market influences the decision of entrepreneurial managers in mid-size firms to internationalize.

Proposition 3. The entrepreneurial manager's decision to internationalize is influenced by products and services that require a high involvement from users.

Complex products and co-design with major customers are a strong characteristic of software and electronics firms and the need for integrated supply systems is a feature of firms in the metal-mechanic sectors working with large customers. As expressed by respondents: 
"We have a product-a product that needs direct near contact with the customer because the product is complex" (respondent case 3).

“We adapt the products to the buyer" (respondent case 6).

"The distribution system is determined by the product. We are now focusing on producing only global products, we do not want to produce products for the French market only” (respondent case 9).

The preferred mode of entry for entrepreneurial manager's dealing with complex product/service is direct linkage with and supporting customers through subsidiaries and head office staff. Trabold (2002) found that product complexity influences the mode of internationalization. Greater product complexity adds costs and can increase the specialization of a product (or equally a service) to few or even a single market which greater complexity, as highlighted in the above comments, increases the difficulty associated with internationalizing. Lower complexity allows a product or service to fit markets more broadly and so increase the scope for international operations. Thus the degree of product-service complexity serves to motivate or hinder an entrepreneurial manager's decision to internationalize as it alters the resource investment necessary to enter markets.

Proposition 4. The entrepreneurial manager's decision to internationalize is influenced by the strength of its customer and network relationships.

The perceived influence of a customer mindset on the internationalization decisionmaking of the entrepreneurial manager was suspected to be a key factor. The discourse from the interviewees provides very strong evidence that the internationalization decision-making was started by 'following the customer' and responding to a customer need or demand:

"We need subsidiaries to keep our customers happy, they need a local person they can talk to" (respondent case 2). 
"Yes-we follow our customers. If they request this then we must work with them wherever they want us to" (respondent case 3).

"We do customer surveys, so we can talk to our final customers get feedback and we feed them into our engineering and product management organization” (respondent firm 6).

"Have to check that the needs of the client are being met. We want to satisfy our customers. Most important thing the entrepreneur developed products with the clients, they decided on the product" (respondent firm 7).

"The company is close to clients? Sure, very close yes. When you transfer an industrial unit it is necessary to work with trust because in such a project you are responsible for many things, and it is important that the client can trust you" (respondent firm 8).

The entrepreneurial managers clearly view themselves to be market and customer oriented with evidence of customized product design and services such as integrated logistics. The association between customer demands and internationalization is evident in the comments and is one of the strongest influences on internationalization from the respondents' perspective. Kwon and Hu (2000) have reported that being market oriented plays a key role in the success of international activities but our findings imply that as market orientation of the entrepreneurial manager becomes more extensive, they gain more confidence in pursuing their international market opportunities. Interestingly, this suggests that entrepreneurial managers in mid-sized firms may be predisposed to develop extensive customer linkages before undertaking the entrepreneurial act of international market entry. That is, until their market understanding and customer linkages have been sufficiently built, it would appear from the results that they would shy away from, internationalization. This suggests a sophisticated mix of customer orientation and entrepreneurial imperative in internationalization for entrepreneurial managers. Unfortunately, it is difficult to pinpoint in 
our findings which one takes precedence or whether it is a decision that combines both. Regardless, this holds implications for studies of international market orientation (Cadogan, Cui, Morgan, \& Story, 2006) and market and entrepreneurial orientations (Bhuian, Menguc, \& Bell, 2005). Given that our respondents emphasize the importance of customer closeness and response in internationalization decision-making, it would appear that centralizing the customer into the core actions of the firm is an essential prerequisite to international activity but may in doing so slow down a decision to internationalize until linkages are sufficiently built. This may be a form of risk management however, which contradicts international entrepreneurship theory which specifies entrepreneurial managers to be risk seekers (McDougall \& Oviatt, 2000), because closeness to customer prior to internationalization mitigates part of the business risk but ironically adds a form of market risk because the firm may become over-dependent on the key customer in the initial internationalization period. This suggests the need for far more research into the nature of 'risky' decisions.

Several other important customer-related observations were also made by respondents. There was evidence that whatever the market entry mode the entrepreneurial manager selects, their preference was for some direct interaction with the customer and to extend products developed for customers in the domestic market were extended into international markets:

"We need to be trusted by the customer because we develop their products. We do not give them products, we give them our know-how, it is not visible. We have some niche products specialized around a customer. We change products to customer demands. We have to be close to our customer, our technical department, our engineering department they work very closely with the customer" (respondent case 10).

"When we moved into the market in 1993 it was on the back of developing our domestic products for a customer in the USA. We followed the customer to other locations in international markets. We are close to our customers" (respondent case 15). 
These statements underline the common theme that internationalizing decisions cannot be made independent of the potential customer or the firm's current customers. It is evident that a desire to better serve the current customer base is equally important as business growth through internationalization. Often this distinction is unclear in the internationalization literature. These entrepreneurial managers are not necessarily following the customer but rather are strengthening the opportunity and mitigating risk by waiting for the right time. Nonetheless, careful consideration is needed into how factors motivating internationalization might influence the relationship between the firm and its current and potential customers.

Given the strength of the influence of customer relationships on the decision to internationalize and the relative lack of strength of influence of other network ties or relationships we have modified our literature based proposition. Note in the following modified proposition 4 we have excluded 'network relationships':

Modified Proposition 4. The entrepreneurial manager's decision to internationalize is influenced by the strength of its customer relationships..

Proposition 5. The entrepreneurial manager's decision to internationalize is influenced by the availability of adequate internal resources.

None of the entrepreneurial managers expressed the opinion that resources constrained or influenced their decision to internationalize, an interesting contradiction given the discussion above and expectations laid out in RBV and resource-advantage theories. One respondent discussed some financial difficulties caused by the lack of capital and the underperformance of management in a foreign subsidiary however this was not perceived as a resource problem as the firm quickly resolved the issue and recovered the situation.

"With the first subsidiary (in the USA) totally undercapitalised the entire group is basically living from hand to mouth as we say in Germany. The biggest hurdle for such an expansion is two fold. The one is definitely while you are so busy in your domestic 
market then a faraway subsidiary requiring attention is hard to support. The second aspect certainly is local management quality” (respondent case 6).

This finding is at variance with the literature on resource constraints (Kedia \& Chokar, 1986) but is consistent with Crick and Spence (2005) who determined that the resource-based view of the firm does not fully explain internationalization decisions by entrepreneurs. A possible reason might be found in the nature of the entrepreneurial mindset. From Lumpkin and Dess' (1996) theory of entrepreneurial orientation, which views it as methods used by firms to act and take entrepreneurial decisions, entrepreneurial managers tend to be tolerant of taking risk (such as internationalization) in the face of resource uncertainty and are willing to commit scarce resources regardless because they believe in the rewards available to them. For example, their knowledge of the customer or strong ties to their customer base might ease the decision to internationalize which allows the firm to ignore resource concerns because the nature of the investment is more clearly known. Or, there simply exists an overriding business case to internationalize irrespective of apparent resource limitations (e.g., competitor activity). Resource limitations are problematic only when the requirements are unclear but if the firm has greater knowledge of what the international investment decision requires, then limited resources may not necessarily hinder decisionmaking. This is not to say that it might not hinder performance. The prevailing logic would be that some moderation effect is likely. Further research is thus needed to understand how resources influence the internationalization decision-making process of entrepreneurial managers in mid-sized firms and what role they might play in internationalization process given that our findings contradict expectations from extant resource-based theory.

It appeared that managers in our study were tolerant of resource constraints and so tolerant of the risks of their application. Even though we find no evidence that the presence of adequate resources itself motivated a decision to internationalize by entrepreneurial managers 
in mid-sized firms, it is likely that the degree of this risk tolerance moderates the effect of other factors on the decision to internationalize. For example, in the face of high productservice complexity or closeness to customers and other network relations motivating internationalization, a low tolerance of resource-based risk might prevent managers from taking the decision to internationalize. The presence of limited resources is irrelevant here but rather the extent to which the manager is willing to tolerate diverting resources to new and uncertain activities will likely influence a decision to internationalize irrespective of the magnitude of favourable factors motivating the decision. Thus:

New proposition. The degree of resource-based risk tolerance moderates the impact of the motivating conditions on the decision to internationalize.

Proposition 6. The entrepreneurial manager's decision to internationalize is influenced by their prior history of decision-making.

Respondents rarely referred to past events as influencing decision-making. The analysis of the responses did not yield any quotes discussing this as an issue. This is contrary to research which views firm strategic behaviour as being path dependent based on the past experience of the entrepreneurial manager or management team (Nelson \& Winter, 1982; Reuber \& Fischer, 1997). This is encouraging as it highlights that entrepreneurial activity is indeed path breaking in the firm. We speculate that the confidence to do so likely comes from the entrepreneurial manager's assessment of the business case and willingness to break from tradition. This is perhaps surprising given that research on entrepreneurial cognition suggests that experienced entrepreneurs tend to rely on experiences and prior biases to make decisions (Busenitz \& Barney, 1997), yet, might be explained by the fact that entrepreneurial cognition is an intangible and idiosyncratic phenomenon. There is therefore a danger of imposing interpretations on entrepreneurs' behaviours and drawing false conclusions (Zahra et al., 2005). The entrepreneurial managers in our study may make decisions on the basis of 
experience that informs their thinking but it is difficult to draw and evaluate their behavioural consequences, suggesting the need for further research.

At several points in the discussion so far, it has emerged that where theory-driven factors were found not to influence the decisions of entrepreneurial managers in our study of mid-sized firms to internationalize, in almost each instance managers appeared to be driven by the strength of the business case over above culture, presence of adequate resources, or prior decision-making. We suggest that despite the presence of motivating conditions, entrepreneurial managers behave in a risk-managing way (rather than risk-seeking) by seeking to establish a business case to internationalize. This implies that the strength of the business case might moderate the motivational force of favourable conditions. This would help explain why in the presence of strong customer and network relationships, for example, some managers might still not internationalize their mid-sized firms. This approach bears similarity to the notion of strategic entrepreneurship (Ireland et al., 2003) whereby unless entrepreneurial managers foresee a real basis for competitive advantage to pursue an opportunity, they will deem the business case to internationalize inadequate despite favourable conditions to do so. Thus:

New proposition. The strength of the business case over and above the opportunity moderates the impact of the motivating conditions on the decision to internationalize.

Proposition 7. The entrepreneurial manager's decision to internationalize is influenced by their tacit knowledge about international opportunities and how to leverage capabilities.

The evidence from the qualitative research is that the entrepreneurial manager has a very strong influence on the internationalization of the firm. The strength of this influence is evidenced by the importance attributed by respondents to the entrepreneurial manager's vision and involvement in internationalization strategies. As such, the internationalization 
decision could largely be based on their own diagnosis of the situation and tacit knowledge as an entrepreneur. The key aspect to this finding is that so far we have simply discussed internal and external factors impinging upon the decision to internationalize but here the focus is on entrepreneurial managers' own biases in this decision. Often, the role of the person itself is suspended as industry and firm factors are assessed. Our finding that the latter is merely food into the mind of the entrepreneur which is then combined with bias and tacit knowledge implies the decision-making process is more complex than typically conceptualized.

"Very strong desire to become international from the beginning. If we have a customer in Germany we can do it here we should try to be everywhere. We think global act local - this is our motto" (respondent case 1).

"I believe you cannot go to an export market without returning with an order, you must be present in export markets" (respondent case 9).

"I am very globally thinking. My objective in the next five years is to increase exportsthe final sales-50\% international, 50\% domestic. A big change" (respondent case 10).

The entrepreneurial manager was mainly responsible for initiating export sales activities. Even when the firm's international business developed and other specialist export managers took on the responsibility for international sales, the simple organizational structure for exports left the entrepreneurial manager still actively involved in domestic and international sales negotiations in most cases. In mid-sized firms, the entrepreneurial manager remains a critical component of the firm's human capital. As suggested by human capital theory, the stronger the skills of this individual and the greater the extent of his or her tacit knowledge and experiential learning the greater the likelihood that this person will drive international decision-making (Westhead et al., 2001). As a figurehead in the firm, the entrepreneurial manager sets the firm's vision and galvanizes support for a course of action irrespective of whether it is the strongest course. However, it remains unclear how they 
achieve support for a vision of the firm's future. Whilst some leaders are undoubtedly charismatic, a political approach could well occur. It would therefore be of interest to study whether alternatives styles of leadership among entrepreneurial decision-makers influence internationalization.

\section{Conclusions, Recommendations, Strengths and Limitations and Future Research}

In this study we sought to contribute to our knowledge of international entrepreneurship by examining what factors motivate the decision of entrepreneurial managers in mid-sized firms to internationalize and therefore undertake the act of international market entry, the fundamental act of international entrepreneurship. This was in response to a dearth of study into international entrepreneurship activity in these types of firms (Dimitratos and Jones, 2005). We responded to the question: Why do entrepreneurial managers' in mid-sized firms take the decision to internationalize and enter foreign markets? The range of research and theorizing in the area of entrepreneurship and international business has led to some confusion for stakeholders both in terms of the locus of international entrepreneurship, what represents an act of entrepreneurship itself, and what factors motivate entrepreneurial managers in mid-sized firms to take a decision to internationalize. First, we chose to follow Lumpkin and Dess (1996) among others who define the essential act of entrepreneurship as one of market entry. Then, we explored multi-theoretical approaches, a method acknowledged to help clarify situations where confusion has been created through extensive theorizing across fields with little synthesis among them (Malhotra, Agarwal, \& Ulgado, 2003), but stress that attempts to identify a single universal theory of the internationalization decision (international market entry) may be impossible and most likely inappropriate. This is particularly so given the acknowledged differences between small firms and larger established firms (Dean et al., 1998; Henderson, 1999), hence why we chose to 
focus on established mid-sized firms in this study and so attempt to respond to the dearth of research into such firms (Dimitratos and Jones, 2005). We discover that of 7 theory-derived propositions, only 3 appear viable explanations of entrepreneurial managers' decision to internationalize in mid-sized firms but our analysis leads us to draw a further 3 new practicebased propositions. Following case data analysis, our revised and grounded propositions are:

P1: Product-service complexity influences the decision of entrepreneurial managers in mid-sized firms to internationalize.

P2: Strong customer relationships influence the decision of entrepreneurial managers in mid-sized firms to internationalize.

P3: Tacit knowledge and vision influences the decision of entrepreneurial managers in mid-sized firms to internationalize.

P4: Perception of a 'psychic' distance between their home and foreign market influences the decision of entrepreneurial managers in mid-size firms to internationalize.

P5: The degree of resource-based risk tolerance moderates the impact of the motivating conditions on the decision to internationalize.

P6: The strength of the business case over and above the opportunity moderates the impact of the motivating conditions on the decision to internationalize.

Figure 1 summarises the original 7 propositions on the left hand side and the original 3 and additional 3 grounded propositions on the right hand side of the figure.

Insert Figure 1 about here

For those who do pursue international activities, it is important to understand what led their entrepreneurial managers to take such a decision so that their experience can inform other managers who may wish to internationalize their firms but struggle to make a sufficient 
case to their stakeholders. From a policy perspective, it allows government bodies to better appreciate why some firms internationalize and how the decision to internationalize could be influenced. We contribute to knowledge by developing a set of propositions for theory and practice of international decision-making by entrepreneurial managers. The adoption of a qualitative research methodology with a theory first approach allowing for development of new propositions grounded in the empirical research resulted in several interesting avenues for future research as well as some recommendations for entrepreneurial managers. The findings, particularly the strong influence of the entrepreneurial decision-maker and the connection with the buyer, provide evidence to support the linkage between the firm and market-based assets. The boundaries between the firm and the market are 'fuzzy' and not, as suggested by export behaviour theory, dichotomous (Leonidou, 1995). An important finding for the development of knowledge and practice is the evidence that these mid-sized firms internationalized through close ties with their domestic and international customers but what became evident in our findings is that such a market orientation may inhibit the speed at which a decision is taken as linkages need to be profound before they are willing to move. The business case for internationalization therefore may override an entrepreneurial imperative, indicating the synthesis of an opportunity-seeking and advantage-seeking mindset (Ireland et al., 2003). Furthermore, the research contributes to knowledge on the internationalization process within contexts of country, culture and firm size. The finding that entrepreneurial managers do not perceive national culture as a major influence, or barrier to internationalization, contradicts export behaviour literature that tends to present culture as a barrier to internationalization. Again this implies that the entrepreneurial manager considers the strength of both the opportunity and business case over any overt cultural difference. However, in our new proposition 4 the internalized perception of cultural distance may have some influence on the entrepreneurial manager's decision to internationalize market entry. 
The evidence from our research on perception of cultural distance by entrepreneurial managers in mid-sized firms is inconclusive and so warrants further research, particularly whether firm-level factors moderate its effect.

Our research of mid-sized firms reveals the lack of perception that resources are a barrier to international growth in contrast to studies of small firms. We concur with Crick and Spence (2005) that resources are but one factor in the decision-making process but resource endowment does not appear to impact the decision-making process. Resources may of course affect subsequent performance but our findings indicate that, contrary to theory, entrepreneurial managers will seek to act without regard to initial resources. This may on the other hand imply that entrepreneurial managers in mid-sized firms are highly confident of being able to access resources from other sources when needed, indicating that network relationships or ability to establish meaningful relationships is a critical factor in the decision to internationalize.

Since the favourability of industry structure did not appear to motivate entrepreneurial activity also, it suggests that the allocation of resource may be a controlled process. Even if the presence of adequate resource does not influence the decision, this observation still implies that the allocation of the resource bundle itself might be a consideration. This again points toward the strategic management of entrepreneurial activity to a far greater extent than presently captured in IE research. As neither resource stock nor the nature of the industry conditions dictated the entrepreneurial manager's actions, it appears that the manager's actions are a product of their own choices and circumstances and not necessarily enforced by the industry or firm conditions. Unquestionably, these issues point toward further research.

One of the strengths of our research is that we made no assumptions about the internationalization decision, rather kept an open mind to allow the respondents in the study to explain their approach. However, there are limitations. First, the findings and the theory has 
not been tested on a larger sample. Generalizability is therefore limited to propositions and not to population. Second, the research could have developed propositions through multiple site visits in a longitudinal study of the firms to capture some of the dynamics of the decision. This could not be done because this type of research requires a larger team of researchers in several countries. A cross-sectional study in four countries is already a major undertaking for a small team. However, we have attempted to explain the dynamics of the internationalization process from the point of view of entrepreneurial managers' decision-making by asking respondents to think about their firms past, present and future policies on internationalization. This methodology is problematic as it relies on memory of past events and possible post-hoc rationalization by respondents. Whilst triangulation was used, it is possible that some error remained. Third, while the research has developed the propositions in diverse countries of Europe, it remains a regional study. The findings regarding culture and internationalization may need re-evaluation if the study were extended to other regions of the world. Overall, given the time and resource constraints, the extensive face-to-face interviews in four countries and the purpose of the paper to develop propositions rather than test hypotheses, the methodology was appropriate.

Our study has sought to offer insight into how entrepreneurial managers in established mid-sized firms arrive at the decision to internationalize and so undertake international entrepreneurship by researching what factors affect their internationalization decision. We have used the extant research in the international business, marketing, entrepreneurship, and to a limited extent the international new venture literature as a basis for framing and establishing propositions in a study of mid-size firms. Our findings add value to the international entrepreneurship literature by providing future researchers with a platform of propositions to further compare and match studies of mid-size firms with those of international new ventures and born globals for example. These firms do possess considerable 
differences but given that the thrust of corporate entrepreneurship research has been to understand how to make larger, more bureaucratic firms as nimble as new, dynamic ventures, a comparison of their internationalization processes, conditions, and decision, might yield significant insight to this literature as well as literature on international entrepreneurship in general.

We add another piece to the puzzle of our understanding of entrepreneurial behaviour and internationalization. Established mid-sized firms have so far represented a largely neglected research context in international entrepreneurship study but represent a fertile area for future researchers. Future studies could seek to complement this study by identifying factors that demotivate a decision to internationalize. Finally, an empirical analysis of our propositions would help managers and policy-makers to understand how to increase value from this important subset of firms in the economy. This we believe will add richness to the debate of internationalization theory and knowledge. 


\section{References}

Andersen, O. (1993). On the internationalization process of firms: a critical analysis, Journal of International Business Studies, 24/2, 209-231.

Andersen, O. (1997). Internationalization and Market Entry Mode: A Review of Theories and Conceptual Framework, Management International Review, 37/2, 27-42.

Arthanassiou, N. \& Nigh, D. 2000. Internationalization, tacit knowledge and the top management teams of MNCs. Journal of International Business Studies, 31/3, 471-487.

Bell, J. (1995). The Internationalization of Small Computer Software Firms-a Further Challenge to Stages Theories, European Journal of Marketing, 29/8, 60-75.

Bhuian, S.N., Menguc, B., \& Bell, S.J. (2005). Just entrepreneurial enough: The moderating effect of entrepreneurship on the relationship between market orientation and performance', Journal of Business Research, 58, 9-17.

Brannen, M.Y. (2004). When Mickey Loses Face: Recontextualization, Semantic Fit, and the Semiotics of Foreignness, Academy of Management Review, 29, 593-616.

Bürgel, O. (2000). The Internationalisation of British Start-up Companies in HighTechnology Industries. ZEW Economic Studies 9. Mannheim: Physica-Verlag.

Busenitz, L.W. \& Barney, J.B. (1997). Differences between entrepreneurs and managers in large organizations: Biases and heuristics in strategic decision-making, Journal of Business Venturing, 12/1, 9-30.

Busenitz, L.W. Gomez, C. \& Spencer, J.W. (2000). Country Institutional Profiles: Unlocking Entrepreneurial Phenomena, Academy of Management Journal, 43/5, 994-1003.

Cadogan, J.W., Cui, C.C., Morgan, R.E., \& Story, V.M. (2006). Factors facilitating and impeding the development of export market-oriented behavior: A study of Hong Kong manufacturing exporters, Industrial Marketing Management, 35, 634-647,

Calantone, R.J., Cavusgil, S.T., Schmidt, J.B., \& Shin, G.-C. (2004). Internationalization and the Dynamics of Product Adaptation-An Empirical Investigation. Journal of Product Innovation Management, 21, 185-198.

Campbell, A.J. \& Wilson, D.T. (1996). Managed Networks-Creating Strategic Advantage. In D. Iacobucci (ed.), Networks in Marketing: Newbury Park: Sage, 125-143.

Cardone-Riportella, C., Alvarez-Gil, M..J, Lado-Couste, N., \& Sasi, V. (2003). The Relative Effects of Client-Following and Market-Seeking Strategies in the Internationalisation Process of Financial-Service Companies: A Comparison of Spanish and Finnish Entities, International Journal of Management, 20, 384-394.

Cloninger, P.A. 2004. The effect of service intangibility on revenues from foreign markets, Journal of International Management, 10, 125-146.

Collis, D.J. (1991). A Resource-based analysis of global competition: The case of the bearings industry, Strategic Management Journal, 12, 49-68.

Coviello, N.E. \& Jones M.V. (2004). Methodological issues in international entrepreneurship research, Journal of Business Venturing, 19, 485-508.

Coviello, N.E. \& Munro, H.J. (1995). Growing the Entrepreneurial Firm: Networking for International Market Development, European Journal of Marketing, 29/7, 49-62.

Crick, D. \& Spence, M. (2005). The internationalisation of 'high performing' UK high-tech SMEs: A study of planned and unplanned strategies, International Business Review, 14/2, 167-185.

Dean, T.J., Brown, R.L., \& Bamford, C.E. (1998). Differences in Large and Small Firm Responses to Environmental Context: Strategic Implications from a Comparative Analysis of Business Formations, Strategic Management Journal, 19, 709-728

Dichtl, E., Koeglmayr, H., \& Mueller, S. (1990). International orientation as a precondition for export success, Journal of International Business Studies, 21/1, 23-40. 
Dimitratos, P. \& Jones, M.V. (2005). Future directions for international entrepreneurship research, International Business Review, 14, 119-128.

DTI (2004). A Government Action Plan for Small Business. London: Department of Trade and Industry Publication (URN 03/1592).

Dwyer, S. Mesak, H., \& Hsu, M. (2005). An Exploratory Examination of the Influence of National Culture on Cross-National Product Diffusion, Journal of International Marketing, 13/2, 1-27.

Ekeledo, I. \& Sivakumar, K. (2004). The Impact of e-commerce on Entry-Mode Strategies of Service Firms: A Conceptual Framework and Research Propositions, Journal of International Marketing, 12/4, 46-70.

Europe's 500. (2005.). Key results for 2004. Retrieved December 19, 2005, from http://www.europes500.com/pages2/key_results.htlm.

Ford, D. Gadde, L.E. Håkansson, H. Lundgren, A. Snehota, I. Turnbull, P., \& Wilson, D. (1998). Managing Business Relationships. Chichester: John Wiley and Sons.

Garner, G. (1982). Comparative Export Behaviour of Small Canadian Firms in the Printing and Electrical Industries. In M.R. Czinkota and G. Tesar (eds.), Export Management: An International Context, New York: Praeger Publishers, 113-131.

Gimeno, J.F. Folta, T.B. Cooper, A.C., \& Woo, C.Y. (1997). Survival of the Fittest? Entrepreneurial Human Capital and the Persistence of Underperforming Firms, Administrative Science Quarterly, 42/4, 750-783.

Glaser, B.G. \& Strauss, A.L. (1967). The Discovery of Grounded Theory: Strategies for Qualitative Research. Chicago: Aldine.

Gummesson, E. 2006. Qualitative research in management: addressing complexity, context and persona. Management Decision, 44/2, 167-179.

Hannan, M.T. \& Freeman, J.H. (1977). The Population Ecology of Organizations, American Journal of Sociology, 82, 929-964.

Hayton, J.C. George, G., \& Zhara, S.A. (2002). National Culture and Entrepreneurship: A Review of Behavioral Research, Entrepreneurship Theory and Practice, 26/4, 33-52.

Henderson, A.D. (1999). Firm Strategy and Age Dependence: A Contingent View of the Liabilities of Newness, Adolescence, and Obsolescence, Administrative Science Quarterly, 44, 281-314.

Hofstede, G. 1980. Culture's Consequences: International Differences in Work-Related Values. Beverly Hills, CA: Sage.

Hofstede, G., \& Hofstede, G.J. (2005). Cultures and Organizations - Software of the Mind. New York: McGraw-Hill

Homburg, C. (2000). Closeness to customers of Industrial Firms: Conceptualization, Success Effects and Determinants (3rd ed.). Gabler: Wiesbaden.

Hunt, S.D. (2002). Foundations of marketing theory. Armonk, NY: M.E.Sharpe.

Hymer, S.H. (1976). The international operations of national firms: A study of direct foreign investment. Cambridge: MIT Press.

Ireland, R.D., Hitt, M.A., \& Sirmon, D.G. (2003). A Model of Strategic Entrepreneurship: The Construct and its Dimensions, Journal of Management, 29, 963-989.

Johanson, J., \& Vahlne, J. (1977). The internationalization process of the firm: a model of knowledge development and increasing foreign market commitments. Journal of International Business Studies, 8/1, 23-32.

Jones, M.V. \& Coviello, N.E. (2005). Internationalisation: Conceptualising an entrepreneurial process of behaviour in time, Journal of International Business Studies, 36, 284-303.

Kedia, B.L. \& Chokar, J. (1986). Factors Inhibiting Export Performance in Firms: An Empirical Investigation, Management International Review, 26/4, 33-44. 
Kim, Y.K. \& Kang, J. (2001). The Effects of Ethnicity and Products on Purchase Decision Making, Journal of Advertising Research, 41/2, 39-48.

Knickerbocker, F.T. (1973). Oligopolistic reaction and multinational enterprise. Boston: Harvard Graduate School of Business Administration.

Kwon, Y.-C. \& Hu, M.Y. (2000). Market orientation among small Korean exporters, International Business Review, 9/1, 61-75.

Lacey, C. (1976). Problems of Sociological Research: A Review of the Methodology of Hightown Grammar. In M. Shipman (ed.), The Organization and Impact of Social Research, London: Routledge and Kegan Paul, 63-81.

Leiblein, M.J. \& Reuer, J.J. (2004). Building a foreign sales base: the roles of capabilities and alliances for entrepreneurial firms, Journal of Business Venturing, 19, 285-307.

Leonidou, L.C. (1995). Export stimulation research: Review, evaluation and integration. International Business Review, 4/2, 133-156.

Lumpkin, G.T. \& Dess, G.G. (1996). Clarifying the Entrepreneurial Orientation Construct and linking it to Performance, Academy of Management Review, 21/1, 135-172.

Madhok, A. (1997). Cost, Value and Foreign Market Entry Mode: The Transaction and the Firm, Strategic Management Journal, 18, 39-61.

Malhotra, N.K. Agarwal, J.A., \& Ulgado, F.M. (2003). Internationalization and Entry Modes: a Multitheoretical Framework and Research Propositions, Journal of International Marketing, 11/4, 1-31.

McDougall, P.P. \& Oviatt, B.M. (2000). International Entrepreneurship: The Intersection of Two Research Paths, Academy of Management Journal, 43, 902-908.

Mitchell, R.K. Smith, B. Morse, E.A. Seawright, K.W. Peredo, A.M. \& McKenzie, B. (2002). Are Entrepreneurial Cognitions Universal? Assessing Entrepreneurial Cognitions Across Cultures, Entrepreneurship Theory and Practice, 26/4, 9-32.

Mitchell, R.K. Smith, B. Seawright, K.W., \& Morse, E.A. (2000). Cross-Cultural Cognitions and the Venture Creation Decision, Academy of Management Journal, 43/5, 974-993.

Miles M.B. \& Huberman, M.A. (1994). Qualitative Data Analysis. Thousand Oaks: Sage.

Nelson, R.R. \& Winter, S.G. (1982). An Evolutionary Theory of Economic Change. Cambridge, M.A.: Harvard University Press.

Nordström, K.A. \& Vahlne, J-E. (1994). Is the Globe Shrinking? Psychic Distance and the Establishment of Swedish Sales Subsidiaries during the Last 100 years. In M. Landeck (ed.,) International Trade: Regional and Global Issues, New York: St. Martin’s Press.

Oviatt, B.M. \& McDougall, P.P. (2005). Defining International Entrepreneurship and Modeling the Speed of Internationalization, Entrepreneurship Theory and Practice, 29/5, 537-553.

Peng, M.W. (2001). The resource-based view and international business. Journal of Management, 27, 803-829.

Peng, M.W. (2004). Identifying the big question in international business research, Journal of International Business Studies, 35, 99-108.

Peng, M.W. Charles W.L., \& Wang, D.Y.L. (2000). Schumpeterian Dynamics Versus Williamsonian Considerations: A Test of Export Intermediary Performance, Journal of Management Studies, 37/2, 167-184.

Rangan, V.K. Menezes, M.A. J., \& Maier, E.P. (1992). Channel Selection for New Industrial Products: A Framework, Method, and Application, Journal of Marketing, 56/3, 69-82.

Rao, C.P. (1990). Impact of domestic recession on export marketing behaviour. International Marketing Review, 7/2, 54-65.

Reuber, R.A. \& Fischer, E. (1997). The influence of the management team's international experience on the internationalization behaviours of SMEs, Journal of International Business Studies, 28/4, 807-822. 
Sirmon, D.G., Hitt, M.A., \& Ireland, R.D (2007). Managing firm resources in dynamic environments to create value: Looking inside the black box, Academy of Management Review, 32/1, 273-292.

Sousa, C.M.P. \& Bradley, F. (2006). Cultural Distance and Psychic Distance: Two Peas in a Pod?, Journal of International Marketing, 14/1, 49-70.

Stevenson, H.H. \& Jarillo, J.C. (1990). A paradigm of entrepreneurship: entrepreneurial management. Strategic Management Journal, 11/Summer Special Issue, 17-27.

Strauss, A. \& Corbin, J. (1998). Basics of Qualitative Research (2 ${ }^{\text {nd }}$ ed.). Thousand Oaks: Sage.

Tan, J. (2002). Culture, Nation, and Entrepreneurial Strategic Orientations: Implications for an Emerging Economy, Entrepreneurship Theory and Practice, 26/4, 95-111.

Thompson, D.V. Hamilton, R.W., \& Rust, R.T. (2005). Feature Fatigue: When Product Capabilities Become Too Much of a Good Thing, Journal of Marketing Research, 42, 431-442.

Trabold, H. (2002). Export intermediation: An empirical test of Peng and Ilinitch, Journal of International Business Studies, 33/2, 327-344.

Urban, G.L. \& von Hippel, E. (1988). Lead User Analyses for the Development of New Industrial Products, Management Science, 34/5, 569-582.

Vargo, S.L. \& Lusch, R.F. (2004). Evolving to a New Dominant Logic for Marketing, Journal of Marketing, 68/1, 1-17.

Vernon, R. (1966). International Investment and International Trade in the Product Life Cycle, Quarterly Journal of Economics, 80, 190-207.

Wernerfelt, B. (1984). A Resource-Based View of the Firm, Strategic Management Journal, 5/2, 171-180.

Westhead, P. Wright, M., \& Ucbasaran D. (2001). The internationalization of new and small firms: A resource-based view, Journal of Business Venturing, 16/4, 333-358.

Wind, Y. Douglas, S.P., \& Perlmutter, H.V. (1973). Guidelines for Developing International Marketing Strategies. Journal of Marketing, 37, April, 14-23.

Wong P. Ho, Y., \& Autio, E. (2005). Entrepreneurship, Innovation and Economic Growth: Evidence from GEM Data, Small Business Economics, 24/3, 335-50.

Wright, R.W. \& Ricks, D.A. (1994). Trends in international business research: Twenty-five years later. Journal of International Business Studies, 25, 687-701.

Yin, R. (1994). Case Study Research: Design and Methods ( $2^{\text {nd }}$ ed.). Newbury Park: Sage.

Zaheer, S. (1995). Overcoming the Liability of Foreignness, Academy of Management Journal, 38, 341-364.

Zahra, S.A. (1993). Environment, corporate entrepreneurship and financial performance: a taxonomic approach, Journal of Business Venturing, 8, 319-340.

Zahra S.A. \& Garvis D.M. (2000). International corporate entrepreneurship: the moderating effect of international environmental hostility. Journal of Business Venturing, 15, 469492.

Zahra, S.A. \& George, G. (2002). International entrepreneurship: The current status of the field and future research agenda. In M.A. Hitt, R.D. Ireland, S.M. Camp \& D.L. Sexton, Eds, Strategic Entrepreneurship: Creating a New Mindset, Oxford: Blackwell Publishers.

Zahra, S.A. Korri, J.S., \& Yu, J. (2005). Cognition and international entrepreneurship: implications for research and international opportunity recognition and exploitation. International Business Review, 14, 129-146. 
TABLE 1

Case Study Profiles

\begin{tabular}{|c|c|c|c|}
\hline $\begin{array}{l}\text { Case company industry } \\
\text { sector, country, year } \\
\text { founded }\end{array}$ & $\begin{array}{l}\text { Main customer market } \\
\text { sectors }\end{array}$ & $\begin{array}{l}\text { Number of Directors } \\
\text { Number of employees } \\
\text { Year founded }\end{array}$ & $\begin{array}{l}\text { Position (s) of } \\
\text { respondents }\end{array}$ \\
\hline $\begin{array}{l}\text { Case } 1 \text { Computer and } \\
\text { Internet Services } \\
\text { Germany }\end{array}$ & Financial services & $\begin{array}{l}5 \text { Board members } \\
130 \text { employees } \\
1974\end{array}$ & $\begin{array}{l}\text { Marketing director } \\
\text { (Board member) \& public } \\
\text { relations manager ( } 2 \text { ) }\end{array}$ \\
\hline $\begin{array}{l}\text { Case } 2 \text { Computer and } \\
\text { Internet Services } \\
\text { Germany }\end{array}$ & $\begin{array}{l}\text { Large projects-public \& } \\
\text { private }\end{array}$ & $\begin{array}{l}3 \text { Board members } \\
410 \text { employees } \\
1980\end{array}$ & $\begin{array}{l}\text { Marketing director } \\
\text { (Board member) }\end{array}$ \\
\hline $\begin{array}{l}\text { Case } 3 \text { electro plating } \\
\text { (SIC 3471) Germany }\end{array}$ & $\begin{array}{l}\text { Mobile telephone } \\
\text { manufacturers }\end{array}$ & $\begin{array}{l}4 \text { Board members } \\
150 \text { employees } \\
1872\end{array}$ & $\begin{array}{l}\text { Operations director } \\
\text { (Board member) }\end{array}$ \\
\hline $\begin{array}{l}\text { Case } 4 \text { Electrical products } \\
\text { \& cables Germany }\end{array}$ & $\begin{array}{l}\text { Transport- auto and } \\
\text { medical equipment }\end{array}$ & $\begin{array}{l}2 \text { Board members } \\
200 \text { employees } \\
1977\end{array}$ & Managing director \\
\hline $\begin{array}{l}\text { Case } 5 \text { Computer } \\
\text { networks Germany }\end{array}$ & $\begin{array}{l}\text { Many sectors large } \\
\text { OEM's }\end{array}$ & $\begin{array}{l}1 \text { owner entrepreneur } \\
181 \text { employees } \\
1982\end{array}$ & Chairman \\
\hline $\begin{array}{l}\text { Case } 6 \text { Electronic- } \\
\text { computer graphics } \\
\text { Germany }\end{array}$ & Business \& consumer & $\begin{array}{l}2 \text { Board members } \\
375 \text { employees } \\
1986\end{array}$ & Chairman \\
\hline $\begin{array}{l}\text { Case } 7 \text { Software-Internet } \\
\text { France }\end{array}$ & Software houses & $\begin{array}{l}3 \text { Board members } \\
230 \text { employees } \\
1989\end{array}$ & $\begin{array}{l}\text { Marketing Director } \\
\text { (Board member) }\end{array}$ \\
\hline $\begin{array}{l}\text { Case } 8 \text { Plant transfer and } \\
\text { maintenance France }\end{array}$ & $\begin{array}{l}\text { Iron \& steel recycling } \\
\text { plant }\end{array}$ & $\begin{array}{l}1 \text { Board member } \\
185 \text { employees } \\
1976\end{array}$ & $\begin{array}{l}\text { President \& export } \\
\text { manager (2) }\end{array}$ \\
\hline $\begin{array}{l}\text { Case } 9 \text { Electronic } \\
\text { telecoms and datacoms } \\
\text { France }\end{array}$ & Retail, utilities & $\begin{array}{l}3 \text { main board members } \\
245 \text { employees } \\
1974\end{array}$ & $\begin{array}{l}\text { Corporate affairs director } \\
\text { (Board member) }\end{array}$ \\
\hline $\begin{array}{l}\text { Case } 10 \text { Electronic } \\
\text { devices Italy }\end{array}$ & IT and computers & $\begin{array}{l}2 \text { Board members } \\
110 \text { employees } \\
1978\end{array}$ & $\begin{array}{l}\text { President board \& export } \\
\text { manager }(2)\end{array}$ \\
\hline $\begin{array}{l}\text { Case } 11 \text { Electronic } \\
\text { computing equipment } \\
\text { Italy }\end{array}$ & Retailers, Public utilities & $\begin{array}{l}1 \text { owner } \\
105 \text { employees } \\
1984\end{array}$ & President \\
\hline $\begin{array}{l}\text { Case } 12 \text { Plastic } \\
\text { products/components } \\
\text { Italy }\end{array}$ & $\begin{array}{l}\text { White goods-kitchen } \\
\text { equipment }\end{array}$ & $\begin{array}{l}1 \text { owner } \\
333 \text { employees } \\
1976\end{array}$ & President \\
\hline $\begin{array}{l}\text { Case } 13 \\
\text { Automotive stampings- } \\
\text { Italy } \\
\text { Founded } 1976\end{array}$ & $\begin{array}{l}\text { Transport-automotive- } \\
\text { boats }\end{array}$ & $\begin{array}{l}3 \text { board members } \\
101 \text { employees } \\
1976\end{array}$ & Director (Board member) \\
\hline $\begin{array}{l}\text { Case } 14 \\
\text { Agricultural and metal } \\
\text { work-Italy }\end{array}$ & $\begin{array}{l}\text { Transport-automotive } \\
\text { agricultural equipment }\end{array}$ & $\begin{array}{l}1 \text { owner } \\
129 \text { employees } \\
1979\end{array}$ & $\begin{array}{l}\text { President and the quality } \\
\text { manager (2) }\end{array}$ \\
\hline $\begin{array}{l}\text { Case } 15 \text { Software training } \\
\text { material and games UK }\end{array}$ & $\begin{array}{l}\text { Travel \& retail financial } \\
\text { services } \\
\text { telecommunications IT }\end{array}$ & $\begin{array}{l}1 \text { Board member } \\
139 \text { employees } \\
1983\end{array}$ & $\begin{array}{l}\text { Finance Director (Board } \\
\text { member) }\end{array}$ \\
\hline $\begin{array}{l}\text { Case } 16 \\
\text { Electronic components } \\
\text { UK }\end{array}$ & $\begin{array}{l}\text { Computer hardware } \\
\text { industry } \\
\text { Medical equipment }\end{array}$ & $\begin{array}{l}3 \text { Board members } \\
150 \text { employees } \\
1973\end{array}$ & $\begin{array}{l}\text { Export Sales Director } \\
\text { (Board member) and } \\
\text { export salesman (2) }\end{array}$ \\
\hline
\end{tabular}


FIGURE 1

Factors Influencing Entrepreneurial Managers' Decision to Internationalize in Mid-Sized Firms

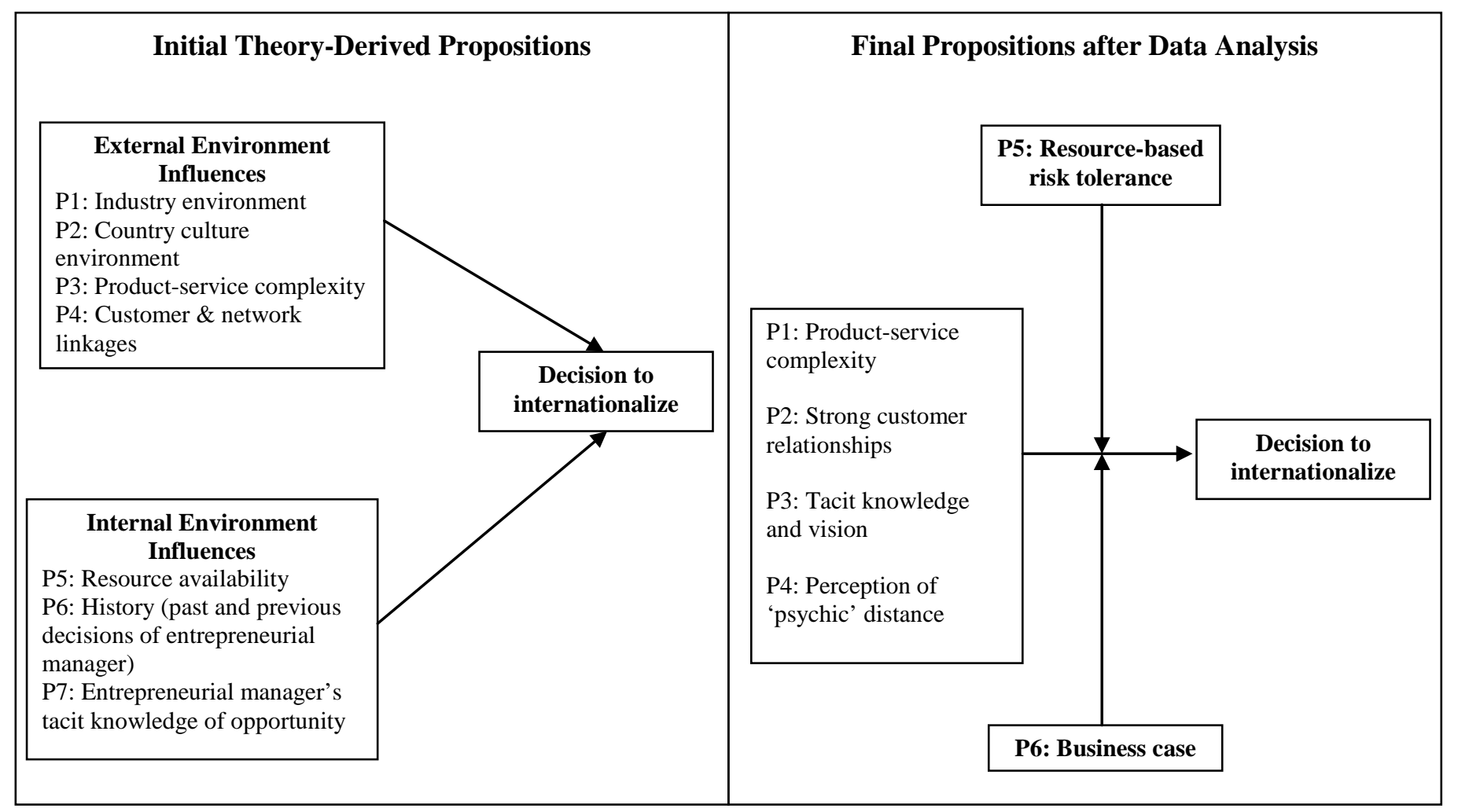




\section{APPENDIX 1 \\ Interview Protocol}

\section{Background and Context}

To probe the dynamics of the process by which firms develop their international business and markets. The field study will attempt to elicit the origins of the sample firms' first moves into international markets. The research questioning will then probe how their international business evolved in terms of the degree which, the process was deliberate and planned and the method(s) of market entry employed.

\section{Current and Future Activities}

The research questioning then probes the firms current situation vis-à-vis international markets and the plans for the future development of exports or international business.

Questions, getting to know the company and its international business

1.Can you tell me about the origins of your company?

2.When did you start to export?

3.How did the export process/business start?

4.Who took on the responsibility for handling/managing your export business?

5.What forms and patterns of market entry modes do you have in your international markets?

6.Was the decision to develop international markets planned manner or did it emerge out of a series of chance contacts or successes?

7. What number of staff is involved in exporting, how is it organised?

Questions re market evolution/dynamics of the international development process

1.Can you recall how your international sales/business grew and did this confirm/change your views about the likelihood of remaining in international markets?

2.Did a sense of commitment to international business emerge in the process of export sales growth?

3.Did you enter markets individually and sequentially or several markets simultaneously?

Questions getting to know how the managers deal with relationships with distributors/licensees/joint ventures etc.,

1. How did you form your links with partners, intermediaries, licensee's etc.,

2. What are the responsibilities of intermediaries' etc.?

3. What is your company's role/responsibilities?

4. How do you approach the task of managing intermediary etc., relations?

Questions related to sales subsidiaries

1. Why did you decide to invest in/set up a sales subsidiary?

2. What role(s)/functions do your sales subsidiaries perform?

3. What roles/functions do the headquarters perform?

4. How do you manage and control your subsidiaries (reporting and planning systems)

5. What are your staffing policies; do you employ local nationals or expatriate managers?

6. How many staff do you employ in foreign subsidiaries?

Questions regarding time spent in foreign markets

1. Who is responsible for overseas sales?

2. How much time each month or year do you or your staff spend in foreign markets?

3. When working in foreign markets how much time is spent with customers or distributors?

Questions related to investment decisions

1. Have you made any investments overseas?

2. What is the form of this investment? - in manufacturing/equity joint venture/sales-services subsidiary/distribution networks?

3. How do you raise capital/finance for overseas investment? 